\title{
Are trade unions effective accounting actors?
}

\section{Introduction}

Eastern European trade unions are expected to take an active part in the transformation process. All the new EU members boast complex institutional frameworks which uphold such participation. Far from being an invention of politicians, union policy involvement has strong roots in the theory and practice of western (neo)corporatism and in democratic theory. And the transformation of socialist economies into market capitalist ones has given a new life to all these arguments.

The starting point of this analysis is an idea put forward by Stark and Bruszt in their 1998 book Post-socialist Pathways. The authors claim that one of the conditions which lead to coherent policy-making is a dense accountability network through which governments are kept in check by organised societal interests such as trade unions. Moreover, these organisations not only keep the government accountable but also participate actively in the decision-making process. The authors entrust unions with great responsibility, but they do not define it clearly. To be fair, they do acknowledge that, between trade unions and government, a complex interaction takes place. They point to the ability of unions to elicit justifications or explanations from the government on a permanent basis as the sign of the existence of an accountability relationship between the two actors. But what exactly does this imply? It is the opinion of the author of this article that 'continuity of relationship' and 'producing justifications' rest on the fulfilment of several other conditions. The article proposes one such set of 'enabling conditions' and observes the extent to which they are fulfilled in selected eastern European cases. In so doing, the article attempts to answer the question whether trade unions are the accounting actors they are expected to be.

The article builds on an analysis of union-government relations in Bulgaria, Czech Republic, Hungary, Poland, Romania and Slovak Republic between 1990 and 2004, using a combination of document analysis (reports and union documents) and a secondary analysis of specialised literature. ${ }^{1}$

The article begins with an overview of the two main theories which uphold the view of trade union empowerment and political activism. The author concludes that eastern European trade unions have been pushed into the current direction by zealous policy advisers (or policy takers), largely disregarding the impact of the area's idiosyncrasies. Unions have been given new institutions and were assumed to be able to fulfil new roles, modelled upon western ones. One of these roles is to be accounting actors vis-à-vis their governments. The second part of the paper takes a closer look at what accountability means and advances five conditions which enable accounting actors to fulfil their roles. The extent to which these conditions are fulfilled in the eastern European context is then discussed. The third part presents the conclusions.

1 The research for this article has been possible due to the support of the Swiss National Fund for Academic Research, which the author gratefully acknowledges. 


\section{From theories combined ...}

The mechanism by which the economist Alexander Gerschenkron so convincingly explained the case of post-war Japan and Germany ${ }^{2}$ appealed to those advising developing countries. It was argued that late developers could profit from the experience of early developers, comparing experiences and taking on the best solutions. The idea that institutions and policies could be copied from one country to another pinpointed this mechanism. Taking over institutions seemed easy enough, but problems became obvious to those who wanted to see them because the context in which the transplant took place could not always accept the new forms. This was either because it had a different culture (Chabal and Daloz, 2006) or because it was missing some elements without which the new forms did not make sense, or simply because the building blocks had a different texture which distorted the new forms, moulding them into something new.

In spite of the warning voices, the process continues in subtle forms. Policies, mechanisms and institutions are not 'exported', but are 'advised', 'suggested' and finally 'imported'. EU enlargement can be largely viewed as a process of institutional transfer: one of the conditions that the newcomers to the EU club had to fulfil was to adopt social dialogue mechanisms which empower the social partners to take part in decision-making. This was a commendable effort (on the part of the newcomers) and a reasonable expectation (on the part of the established members of the club), but it was easily lost from sight that the very history of the two sides of Europe give different weights and different rationales to social partners and their institutions.

(Neo)corporatism was the buzzword of the 1990s, but a transition between two different meanings of the word has been operated and easily overlooked. Initially, corporatism was used to mean a certain structure of interest intermediation, ${ }^{3}$ but it is rather in Lehmbruch's sense of 'concertation' that it is mostly meant nowadays by politicians, analysts and social partners alike. This latter sense switches the emphasis from structures to processes, and understands corporatism as deliberation and consensus-seeking in the decision-making process ${ }^{4}$ (Ost, 2000; Schmitter, 1982; Kubicek, 2000; Schmitter, 1974; Lehmbruch, 1979).

2 In the 1950s, the economist Alexander Gerschenkron wrote about the 'advantages of backwardness': Japan and Germany were destroyed during the Second World War so that, when they began to rebuild, they availed themselves of the latest technologies and industrial processes then available. In the process, they leap-frogged the US and the UK, countries which won the war, because the winners were still using 1930s technology in their industrial plants. Thus, backwardness or destruction by war may help a country gain ground on its more advanced competitors.

3 For Schmitter, corporatism is a structure of interest intermediation in which the 'constituent units are organized into a limited number of singular, compulsory, non-competitive, hierarchically ordered and functionally differentiated categories, recognized or licensed (if not created) by the state and granted a deliberate representational monopoly within their respective categories in exchange for observing certain controls on their selection of leaders and articulation of demands and supports.' (Schmitter, 1974: 93-94).

4 For Lehmbruch, corporatism is 'an institutionalized pattern of policy-formation in which large interest organizations cooperate with each other and with the public authorities not only in the articulation (or even 'intermediation') of interests, but - in its developed forms - in the 'authoritative allocation of values' and in the implementation of such policies.' (Lehmbruch, 1979: 150). 
The change of meaning is only the verbal sign of a more profound change which involves a complex evolution process of labour-capital interaction. Corporatism has traditionally served as a mechanism to strengthen liberal democracies. It has done so by moderating the antagonisms of labour and capital, demonstrating and encouraging them to see that compromising can work in the interest of both (Ost, 2000). In the western world, corporatism evolved with and within social democracy, due to their ideological closeness. The institutionalisation of corporatism satisfied labour's demands to be treated on an equal footing with capital and to have a policy input. Thus, it ensured labour's quiescence and support for democratic polities (Ost, 2000; Schmitter, 1983). However, this type of development was largely missing in eastern Europe (Ost, 2000).

The second source is the theory of democracy, in particular those writings which emphasise the role of civil society as counterbalance to the government. Important to the argument here is the widespread idea that civil society organisations legitimise and restrict state power (Diamond, 1994). In other words, political institutions and personnel are accountable to civil society. From this widespread (and powerful) view developed the idea that, due to their dual character as economic and civic organisations, trade unions can be a powerful means to exert such a control over the political realm, in particular over the government as the source of policies.

Analysis of the interaction between governments and various societal interests in policy-making has led various authors to argue that, through 'embedded policy-making', governments can tune their policies to current conditions, the dangers of institutional imports can be eliminated and policies perceived as 'local products' (Evans, 1995; Amsden et al. 1994). In the final chapter of their book, Stark and Bruszt suggest a developmental model of reform-making in former socialist countries based on a combination of the policy-making and accountability roles played by trade unions (and other organised societal interests). In their view, a government confronted with the major task of transforming a socialist economy into a capitalist one has the best chance of succeeding if it is caught up in strong accountability networks through which other political institutions and societal interests contribute to policy-making and provide control over government policies (Stark and Bruszt, 1998).

Undoubtedly an appealing model. However, are trade unions the accounting actors that they are expected to be? This is the main question of this article, to which we now turn. In the next section, the accountability relationship is analysed theoretically and several of the enabling conditions extracted. Then, the interaction between trade unions and governments of Bulgaria, Czech Republic, Hungary, Poland, Romania and Slovakia will be analysed in accordance with these conditions.

\section{... a new accounting actor arises (?)}

I start with Schedler's complex definition of accountability:

A is accountable to B when A is obliged to inform B about A's (past or future) actions and decisions, to justify them and to suffer punishment in the case of eventual misconduct, (Schedler, 1999: 17)

which emphasises the formal character of the relationship between two actors in which the one being held accountable cannot avoid giving account without accepting a penalty. Schedler is explicit that one cannot speak of accountability when the ac- 
countable actor can choose whether or not to report his or her behaviour or justify his or her actions, and when there is no clear understanding of what happens after the report/account has been given.

As straight-forward as it might seem from looking at the definition, accountability is nevertheless a very dense concept. Its density stems from several sources. Firstly, it is the double nature of the account giving: on the one hand, it implies precision and clarity; a report in terms of initial aims and fulfilled tasks. On the other hand, it means narrative justifications of actions and decisions (Schedler, Diamond and Plattner, 1999; Stark and Bruszt, 1998). Secondly, accountability is a process in which the accounting and accountable actors perform different tasks in the different phases of the account giving process (Schmitter, 2004). Thirdly, accountability is often treated as a good per se (i.e. it is important to achieve accountability), but it also has a strong instrumental value. As such, it can be involved in trade-offs which can often be perceived as costly for decision-makers: for example, some might feel that increasing the accountability of decision-makers to society at large might reduce their efficiency (Keohane and Nye, 2000). ${ }^{5}$

Schedler (1999) distinguishes two dimensions of accountability: answerability and enforcement. Answerability is the most evident one and refers to the obligation of public officials to provide information on, and explain, their actions. Enforcement is less visible and means that the accountable actor can be subjected to sanctions. It does have a slightly negative connotation, but one can actually extend the meaning of enforcement and understand it as the 'threat of sanctions and promise of rewards', since there is much evidence to support the view that actors whose accounts are received positively reap benefits ranging from re-election to contract renewals. The lack of enforcement, while not necessarily leading to the disappearance of accountability in a particular instance, may yet transform it into a diminished type, sometimes merely information giving. To make things further complicated, there are specific situations in which one of these two dimensions does not exist but, nevertheless, accountability is not diminished. ${ }^{6}$ However, in most cases, both dimensions are present.

The classical model of accountability involving two actors in a given polity may be challenged on various fronts. The criticism challenges the model to expand so as to:

Accommodate structural and policy changes that have opened up new spaces for governance and enhanced the demands for greater accountability. (Väyrynen, 2004: 5).

5 This is the case for example with judges or central banks, both institutions with accountability which is deliberately limited.

6 For example, the independence of central banks means that they have to inform the public ex post about their decisions but neither the public nor the politicians can impose a policy course or sanction bankers for their decisions. However, the central bank remains accountable to the public and its representatives in parliament and has to present periodic accounts of its activities. In this case, the 'sanctions' (or rewards) come rather in the form of the trust of other institutions in the bank's ability to perform its tasks and in the credibility it has among similar institutions at international level. In another example, when the people on the streets of București and Timișoara demanded that the Romanian dictator step down, they were not interested in asking him questions about the way he ruled the country or to hear his justifications. They wanted him punished. In this case, the answerability dimension was eliminated in favour of enforcement. 
In other words, it means that new public and private actors, as well as new stakeholders, have to be included in the new accountability mechanisms which can be at national and/or international level (Scholte, 2002; Keohane and Nye, 2000; Bruszt and Stark, 1998).

The classical model of accountability describes a vertical relationship in which representatives are accountable to voters. However, the conceptualisation of vertical accountability embeds several weaknesses. Firstly, it is a once-every-four-years event, so it prevents voters from quickly punishing wrong-doers. Secondly, voters do not have complete information when they make their decisions in front of the ballot box. Alternative sources of information do usually exist, but average voters rarely consult them in order to have a balanced view. Thirdly, citizens vote for a variety of reasons, of which punishing or rewarding the government's activity is only one. Fourthly, vertical accountability targets only elected officials, leaving unchecked a large number of non-elected officials involved at key decision-making points. Thus, horizontal accountability has emerged as a new set of mechanisms intended to complement vertical accountability. Horizontal accountability is the relationship established between state institutions which check each other (Dubrow, 2003; O'Donnell, 1998) and it can take different forms: financial, administrative, professional, moral, legal and constitutional (Schedler, Diamond and Plattner, 1999). ${ }^{7}$

Schedler (1999) argues that, if accountability is to work properly, several conditions have to be met. Firstly, if the accountability relationship is to be meaningful, the accounting actor and the accountable actor need to be independent of each other. Secondly, there has to be a formal setting in which account is given, such as an institution underpinned by a set of rules on how interaction between the accountable and accounting actors takes place. Thirdly, the information exchange has to be meaningful and complete. Fourthly, the accounting actor must be able to inflict a certain punishment, which can be in various forms from loss of position to loss of credibility. ${ }^{8}$ Fifthly, the accounting and accountable actors have to be roughly equal and accept each other as legitimate parties.

In the subsequent analysis, these 'enabling conditions' will be identified as follows: the formal setting refers to the existence and powers of the tripartite institutions (as they are the locus of the organised exchange between unions and government); while information refers to the exchange taking place between government and unions within the tripartite body. The aspect of independence refers to the extent to which unions are close to the government; the assumption is that the closer unions are to the government (or the party in power), the less objective the accounting actor will be.

One can distinguish, then, between roughly three situations: where unions are independent of the government (or party in power); where unions are close to the gov-

7 Without entering into the details, we note that there is no pure form of accountability but, rather, each situation is a mixture of various forms.

8 It is also important to mention that accountability is meaningful also in cases where punishment is not stated ex ante but nevertheless does not lose its force. For example, the constitution may stipulate that the government can be dismissed by parliament, but no law can decide to what degree the credibility of the central bank (or of its governor) is lost due to a mistaken decision. Nevertheless, both government and the governor of the central bank are aware of the consequences of their mistakes. 
ernment (or party in power); and where unions are the government. Balance of power and legitimacy is a more complex issue. Domestic laws and regulations define the representatives who may legitimately take part in tripartite deliberations or negotiations; once this issue is set, there is a high degree of mutual recognition.

There are two other facts which are equally true for all the countries analysed: firstly, trade unions start in a weak position due to the loss of membership (see Table 1) and their falling importance in the workplace; and, secondly, in any relationship which involves a state and a non-state institution, the balance of power is biased $a b$ initio in favour of the former (Crowley and Ost, 2001; Schmitter, 2004). Therefore, given this starting line, the (dis)equilibrium in the balance of power will be discussed in terms of the ability of unions to adopt a unitary stance. If unions are able to adopt common positions then they can, at least theoretically, stand their ground against the government. This last dimension refers to the ability of unions to inflict some sort of penalty on the government. In this respect, the array of instruments at the disposal of unions are the organisation of disruptive actions (strikes and the like); the boycott of tripartite institutions; and the organisation of more symbolic actions such as signing petitions, gathering signatures and publicly exposing the government's wrongdoings.

Table 1 - Trade union membership

\begin{tabular}{|l|c|c|c|c|c|c|}
\hline Country & $\begin{array}{c}\text { CD } \\
\text { Wave1* }\end{array}$ & $\begin{array}{c}\text { CD } \\
\text { Wave2* }\end{array}$ & $\begin{array}{c}\text { ISSP } \\
\mathbf{1 9 9 6} * *\end{array}$ & $\begin{array}{c}\text { ISSP } \\
\mathbf{1 9 9 8} * *\end{array}$ & $\begin{array}{c}\text { EIRO } \\
\mathbf{2 0 0 1}\end{array}$ & $\begin{array}{c}\text { EIRO } \\
\mathbf{2 0 0 3}\end{array}$ \\
\hline Bulgaria & 33.4 & 4.4 & 18.8 & 12.2 & $\mathrm{n} / \mathrm{a}$ & -76.5 \\
\hline Czech Republic & 43.7 & 14 & 35.7 & 17.3 & 30 & \\
\hline Hungary & 36.3 & 11.7 & 15.7 & 13.8 & 20 & $\mathrm{n} / \mathrm{a}$ \\
\hline Poland & 21.8 & 6.7 & 17.5 & 17.5 & 15 & -70.8 \\
\hline Romania & 32.9 & 16.1 & $\mathrm{n} / \mathrm{a}$ & $\mathrm{n} / \mathrm{a}$ & $\mathrm{n} / \mathrm{a}$ & -70 \\
\hline Slovakia & 38 & 19.9 & $\mathrm{n} / \mathrm{a}$ & 26.6 & 40 & -63.6 \\
\hline
\end{tabular}

Sources:

* Consolidation of Democracy in Central and Eastern Europe 1990-2001, a project of GESIS and ZA, Wave 1 (1990-1992) and Wave 2 (1997-2001) ** ISSP - International Social Survey Programme (Waves 1996 and 1998)

EIRO 2001: Industrial Relations in Candidate Countries (these data are self-reported by unions). EIRO 2003: Trade Union Membership 1993-2003; the negative number indicates the difference between the membership rates in 2003 and 1993. As with the previous EIRO 2001 report, membership numbers are as reported by unions.

Note: data on union membership is hardly reliable for various reasons; data collected through surveys generally underestimate membership as workers often do not know whether or not they are union members; self-reported data tend to overestimate membership. However, it is not the exact level that is of importance, but the downward trend. At the beginning of the transition in 1989/90, union membership was roughly $100 \%$ as union membership was compulsory. 


\section{Bulgaria}

The independence of trade unions is a constitutional right, confirmed in various laws concerning union organisation, functioning and public involvement. There are two main trade union organisations in Bulgaria which have representative status at national level: the Confederation of Labour - Podkrepa; and the Confederation of Independent Trade Unions of Bulgaria (CITUB, the heir to the Communist trade union). Right from its creation (in 1989), Podkrepa was associated with the opposition movement. In fact, it was one of the centres around which the first opposition umbrella organisation, the Union of Democratic Forces (UDF), was created in 1990 and it had a decisive role in bringing the first non-communist government to power in 1991. After these elections, Podkrepa withdrew from the opposition movement and pursued an independent approach to public life. CITUB continued to be a close partner of the reformed Communist Party - now the Bulgarian Socialist Party.

As in many other eastern European countries, Bulgarian tripartism was created as early as 1990 as a means to gain public support for reform and to ensure the social peace (Ost, 2000; Gradev, 2001). It started as a general social agreement and was institutionalised in 1991. The adoption of the Labour Code in 1993 strengthened its legal basis. The Bulgarian tripartite body (the National Council of Tripartite Collaboration, NCTC) had a consultative and advisory function. It discussed issues related to labour, income and social protection, economic restructuring and taxation, it elaborated analyses and it published opinions regarding social and economic issues. In 2001, the NCTC was replaced with a new tripartite body (the Economic and Social Council, ESC). According to the law, the ESC is a consultative body expressing the will and the structures of civil society for economic and social development, through which organised interests can participate in public and economic life. The task of the ESC is to elaborate statements on draft laws, national programmes and plans. The law focuses on the structure of the Council, but not on the rights and obligations of the parties involved. To what extent the social partners use it to question the government on its policies is not clear from the information at hand. The law does not contain binding provisions which regulate interaction between the social partners, so it grants the government quite a large amount of room for manoeuvre. ${ }^{9}$ This is visible from the attitude that different governments have adopted inside the tripartite body (Dimitrova, 1999; Detchev, 2003).

The social partners should have a say on draft bills but, quite often, they have been informed at the last minute about government proposals, which has reduced to a minimum the discussions on them and has removed the possibility of making counterproposals (Ost, 2000; Gradev, 2001). Moreover, when time pressures were significant (prior to budget approval or when crises were knocking on the door), the government pushed through its version of draft bills, oblivious to the opinions of the social partners (Gradev, 2001; OECD Economic Surveys on Bulgaria). Often, the government did not relate important information, further emptying the tripartite meetings of content and weakening the ability of the social partners to control them (Ost, 2000; Detchev, 2003).

9 The text of the law can be found at: http://www.esc.bg/legalframework.php?lang=1. 
The ability of unions to organise protests is generally regarded as their most powerful weapon. However, for most of the transformation period, the Bulgarian trade unions did not manage to stir up large-scale strikes directly proportional to the fall in living standards, to mistreatment within the NCTC or to the government's breach of social agreements (Nikolov et al. 2004). The first large-scale protests with political consequences were initiated in 1996 by CITUB, were later joined by Podkrepa and led to the resignation of the socialist government in early 1997. The wave of labour militancy moderated afterwards (Matthes and Thode, 2001). Another means at union disposal was to boycott the working of the tripartite body itself. In fact, the Bulgarian unions walked out of negotiations in 1994 and several times in 1996, and the social dialogue was halted for most of 1996 and 1997. However, the liberal government sworn in in 1997 resumed the dialogue as it needed the support of the social partners for the tough reforms required to save the financial sector.

There are several other unions and federations, but the scene is dominated by Podkrepa and CITUB. The beginning of the 1990s was characterised by inter-union battles for the assets of the Communist trade union federation. Issues of representativeness also divided the unions. By law only CITUB and Podkrepa were granted national representative status up to 2003, but the Videnov government (1995-1996) managed to stir trouble in the union camp by granting a third union access to the NCTC. The enmity between the two main unions quietened and they started to collaborate and focus their actions on the government rather than against each other. The 1996/1997 mass demonstrations were a first sign of change in the union camp. The government remains the stronger actor inside the tripartite body, but the reduction in the inter-union fights and the softening of the ideological gap between them has set the basis for concerted action (Detchev, 2003).

\section{Czech Republic}

The Czech-Moravian Chamber of Trade Unions (CMKOS) is the only union federation representative at the national level (and in the tripartite body) and it has been careful to maintain its institutional and ideological independence.

The tripartite body, the Council of Economic and Social Agreement (CESA), was created in 1990 but, after an initial success - the adoption of legislation which gave unions the power to block dismissals and to access firm-related information - it became increasingly responsible only for the negotiation of the annual general agreement and had less to say on other issues (Ost, 2000). CESA was conceived as a forum for the discussion of a wide range of issues, from long-term development plans to labour-specific issues. The outcome of these discussions was that CESA produced and published analyses and opinions, and gave its approval on draft bills. The golden era of CESA was 1990-1992 when, despite being formed on a voluntary basis and counting on the 'goodwill' of the partners, it discussed over 300 bills and was briefed fully in respect of the plans and measures prepared by the government and individual ministries. After 1992, the right-wing government adopted an increasingly authoritarian style of policy-making, largely disregarding the views of the social partners. The situation became extremely strained in 1994, when the government refused to discuss social security reform, and the tripartite dialogue virtually came to a halt (Kubínková, 1999; Pollert, 2001). In 1995, the tripartite dialogue was resumed in a restricted form. A new tripartite institution was created (the Council for the Dialogue of Social Part- 
ners) in which consultations were to be held only on matters regarding labour law, collective bargaining, wages, and health and safety.

Discussions in the Council did not proceed smoothly. Government representatives tried to evade any discussion of the issues raised, seeking to defer it to a later date. The government representatives were mostly lower-level officials who could barely do more than present the government's proposals. Often, the drafts submitted for discussions arrived irregularly and incomplete, while government plans were to be approved but not discussed (Kubínková, 1999; Ost, 2000).

Confronted with the non-cooperative attitude of the government, CMKOS pulled out of CESA in 1994/95, rejoining only in 1997 when the social democratic government re-created the tripartite body as it needed to establish support for the stabilisation package it had to adopt after the financial crisis of 1996/1997 (Pollert, 1999; Kubínková, 1999). The social democratic government which came to power in 1998 did so after declaring its intentions to reinstate the tripartite dialogue on the same basis as at the beginning of the 1990s. Once in office, it kept its promise and engaged not only trade unions but also NGOs, citizens' initiatives and independent experts in drafting legislation affecting employment, social security or labour protection. The working of the post-1998 tripartite mechanism is not regulated by a specific law; consequently, there is no legally-binding text defining the rights and obligations of the social partners at tripartite level. The basic tripartite document, the statute of CESA, which sets out the rules for its activity, states that the fundamental of CESA is the principle of consensus and 'goodwill' between the social partners (Kroupa, 2006).

The Czech unions were particularly quiet, especially in the first half of the 1990s. Unrest increased in the second half of the 1990 s, but still no major action was recorded (Eurofound, 2004a). Significantly, the answer of the government to protests in the railway, education and health sectors was a draft law which made illegal all strike and protest action other than that organised in relation to a collective agreement (Kubínková, 1999). The social democratic government turned a more friendly face to the social partners and so labour militancy again decreased after 1998.

The unitary structure of the Czech union movement and the low unemployment/ low pay situation in the first half of the 1990s led several authors to the conclusion that CMKOS was a strong counterbalance to the government and was more effective compared with its counterparts in neighbouring countries (Kubínková, 1999; Avdagic, 2003; Stark and Bruszt, 1998). However, a more critical look observes that the government remained the stronger actor and that most union successes can be seen as 'gifts' from a political elite interested in maintaining social peace and in a position to buy it. ${ }^{10}$

10 The good economic conditions of Czech labour in the first half of the 1990s should not be disentangled from the relatively good situation of a country which started the transition without external debt (unlike Hungary and Poland). Privatisation did not bring significant resources to the budget and so, as state resources started to diminish and as the effects of (the lack of) economic reform started to kick in during the second half of the 1990s, labour became more vocal. However, this renewed activism was not influential as the government was forced to adopt harsh measures due to the economic crisis of 1996. 


\section{Hungary}

The Hungarian trade union scene is extremely divided. Besides the reformed communist union (National Confederation of Hungarian Trade Unions, MSzOSz), five other trade union federations are represented in the tripartite national body. The right to form trade unions is constitutionally guaranteed, while the basic law of the country also guarantees the independence of unions from encroachment by state (political) institutions. Unions have established links with the most important political parties but they have not been directly involved in governing activities. ${ }^{11}$

Hungary is proud that, in 1988, it was first among east European countries to have a tripartite institutional National Interest Reconciliation Council (NIRC). On its creation, the NIRC's task was to manage the wage deregulation process, a major reform in the context of a socialist economy (Ost, 2000; Toth, 2001; Eurofound, 2004b). After the first pluralist elections in 1990, it was abolished but replaced with the Interest Reconciliation Council (IRC). In spite of its reconciliatory mission, the new institution was marred by struggles between the unions, fuelled by the repeated tests of representativeness required by the government. ${ }^{12}$ The IRC was created through a voluntary agreement between the social partners and the government. Its basis was not a legal text, but the partners' 'commitment to tripartism' as a means of resolving conflict and deliberating problems. As with other similar institutions in eastern Europe, the Council had mainly consultative and advisory functions regarding labour-related issues. The agreement also stated that the Council was to be consulted on legal drafts of economic, social and labour laws as well as on economic issues of national importance. Within the framework of the IRC, the social partners had the right to be informed, ${ }^{13}$ and to give opinion and consent.

In addition to the IRC, two other tripartite bodies functioned in Hungary: the Interest Reconciliation Council for Budgetary Institutions (with a similar structure and powers as the IRC but applied to budget-maintained institutions); and the Labour Market Fund Steering Committee (a tripartite body concerned with labour market is-

11 Political parties and their unions in Hungary: the Autonomous Trade Union Confederation (ASzSz), the Forum for the Co-operation of Trade Unions (SZEF) and the Confederation of Unions of Professionals (ÉSZT) have sought to maintain independence, although some leaders have become candidates on the lists of the Socialist Party; the Democratic League of Independent Trade Unions (LIGA) sided with the Free Democrats, but the link dissolved with time and it has become more independent; the National Federation of Workers' Councils (MOSz) sided with the Hungarian Democratic Forum but the link evaporated over time, the union adopting a more Christian line; and the National Confederation of Hungarian Trade Unions (MSzOSz) which sided with the Hungarian Socialist Party.

12 Such tests of representativeness were the requirements that unions had to meet in order to be members of various councils and commissions, such as the Self-Governments of Health and Pensions Insurance (1993), the works council and public servants council elections (1993, 1995 and 1998). The years in brackets represent the date of publication of the legislation (Héthy, 1999).

13 The social partners had the right to receive information regarding all economic, social and labour issues that directly or indirectly had a significant effect on them. At their request, the government had to provide information regarding the given issue, either verbally or in writing (Héthy, 1999: 186). 
sues, such as unemployment and training, which was created in 1997). Such a fragmentation of tripartite institutions weakens the social partners, who have to put more effort into co-ordinating their positions in the three bodies. In 1998, the conservative Orban government dismantled the IRC and replaced it with an even more complex structure of tripartite bodies. ${ }^{14}$ By increasing the number of tripartite bodies, dispersing their functions and including more actors, the government ensured that the social partners would not be able to achieve consensus and, consequently, would not be able to pressure the government.

The basis of the tripartite bodies are voluntary agreements, so there are no binding regulations which refer to interaction between the partners. This means that the government enjoys a large amount of freedom while the social partners lack the means to constrain it. More often than not, the right of the social partners to be informed about the government's policies/plans is not respected (Stark and Bruszt, 1998; Ost, 2000; OECD Economic Surveys of Hungary, various years).

The government created the IRC with the aim of ensuring societal support for the reform programme but was not willing to give it too much decision-making power. In fact, in its first years of functioning the government largely ignored the institution it had created, implementing its programme without public consultation. The blockade by Budapest taxi drivers, which found large social support, forced the government to open up more towards the IRC. However, its inclusion remained marginal as the IRC was given the task of drafting the Labour Code and proposing minimum wage guidelines, and was kept away from more important decisions regarding privatisation and budgetary issues. When confronted with a serious fiscal crisis in 1995, the socialist government did not hesitate to impose a radical stabilisation package (the Bokros Plan) without informing ex ante the social partners and without accepting any ex post modifications (Stark and Bruszt, 1998; Ost, 2000; Toth, 2001).

The unions did not hesitate to organise protests. However, most of the strikes which took place between 1992 and 1997 were directed against single employers and were caused by wage issues, privatisation and mass lay-offs, fringe benefits or unfair management. Where the whole sector was concerned, unions preferred to resort to other means, such as collecting signatures. Union protests did not threaten the stability of any government (Eurofound, 2004b).

During most of the 1990s, Hungarian unions were more busy in creating links with political parties than between themselves, contesting each other's legitimacy and quarrelling over the resources of the Communist trade union. Thus, it was not difficult for successive governments to re-shape the tripartite body to the point that it became a mere 'extra' on the public scene (Héthy, 1999; Toth, 2001).

14 The IRC was substituted by the National Labour Council, which retained the IRC's functions in labour issues and pre-legislative consultations related to labour legislation. The newly-created tripartite bodies are the Economic Council (for consultation on economic policy and legislation with the participation - beyond the national trade union confederations and employer associations - of all important economic actors that have no seat on the tripartite IRC, such as the chambers of economy, the financial sector, multinational companies and so on); and commissions to co-ordinate activities related to the International Labour Organisation (ILO) and Hungary's accession to the European Union. The Labour Market Fund Steering Committee (LMFSC) was maintained (Héthy, 1999). 


\section{Poland}

No doubt, Solidarity was the model for what trade unionism should be in eastern Europe, and yet it became the greatest disappointment. To a certain extent, it followed the same destiny of any opposition movement which was focused on a single target: it was strong and had public impact as long as it had a natural enemy. Once the Communist Party disappeared, Solidarity had to face a world in which it had emerged as a winner and which it had to manage. However, this new managerial task required radical changes in the union itself. To a large extent, much of the recent history of Poland can be understood in terms of Solidarity coming to terms with its new self.

Poland stands out as the only case in eastern Europe in which a trade union turned into a political party and twice won elections with strong enough majorities to form a government. Poland also stands out as the only country where this trade union-dominated government undertook the task of introducing liberal economic reforms, doing so with an enthusiasm which translated into anti-union measures. It is true that, in the end, this 'too neo-liberal' attitude of trade unionists-turned-politicians led to a split in the movement between the trade union and the political party wings of Solidarity. However, for the purposes of this article, it is important to note that, for extended periods of time (1991-1995 and 1997-2001), it was very difficult, if not impossible, to disentangle the trade union from the government. It is equally important to observe that the overlap between the two was not forced - and that, therefore, one cannot talk of an encroachment by the government (as a political institution) on the trade union (as a representative of labour interests). It is, rather, a task which was consciously assumed by the latter (Stark and Bruszt, 1998; Ost, 2000, 2001, 2002).

The other part of the trade union movement was formed of the reformed former communist trade union (OPZZ) which had its own share of struggles: to shake off the communist legacy and to find a place for itself in the public space. OPZZ developed a preference for social democratic parties (and was openly an ally of SDL when the social democrats were in power between 1995-1997), but it did not take a seat in the government.

Due to the presence of Solidarity in the first non-communist government, it was assumed that there was no need for a tripartite forum since labour already had its voice in the political sphere and workers were the main engine of the transformation. Therefore, the Polish tripartite body (the Tripartite Commission) was formed only in 1994 when Solidarity (the union) started to break away from Solidarity (the party) and the latter needed an institutional framework to collect and balm labour grievances (Ost, 2000, 2002). ${ }^{15}$ The Commission's role was to assess economic mechanisms and to present its opinions and resolutions concerning remuneration and employment policies in the public sector and on social services policy and pay policy instruments, etc. The Commission was a consultative body and its decisions took the form of non-binding guidelines. Both Solidarity and OPZZ tried to influence policy-making not though the Tripartite Commission but rather through parliament, where they had gained representation. Thus, the visibility of the Tripartite Commission indirectly increased due to the political implications of its members, especially the trade unionists.

15 The Tripartite Commission was preceded by the signing in February 1993 of the StateOwned Enterprise Pact (by all registered national trade unions, including small ones, at the invitation of the government). 
The situation changed after the 2001 elections, when trade unionists lost their representation in parliament. They turned their attention to the Tripartite Commission and attempted to co-operate more within this institution as the government sided with the entrepreneurs. ${ }^{16}$ The Tripartite Commission thus enjoyed more trust from unions, but legally it was still relatively weak as it produced only consultative, non-binding opinions. The only decision-making power it has refers to wage policy - it sets the minimum wage and this decision is binding on the government. However, if the social partners do not reach agreement, the government has the right to impose its option (Sobótka, 1999; Gardawski, 2002; Eurofound, 2004c; Czarzasty, 2006).

The difficulties inside the Tripartite Commission stemmed first and foremost from the confrontational attitude between the two trade unions (Ost 2000, 2001; Czarzasty, 2006) which made consensus-building difficult. Other sources of troubles were the contested representative status of the employer associations and the inclusion of other interest groups. The strained relations between the two unions led to a boycott of the Tripartite Commission roughly between 1997 and 2000 (Ost, 2000). This boycott was not so much a reaction to the policies of the government but rather a matter of principle: Solidarity protested against the measures taken by the socialist government (even if they were to the advantage of workers); and, when Solidarity won the elections again, OPZZ adopted the same attitude (Ost, 2001).

Unions have organised strikes and other protests related to the impact of the reforms, which allowed them to extract some benefits for their members. However, this activism did not threaten government stability, reforms were proceeded with as planned (OECD Economic Surveys on Poland, various years) and there were no signs of a change of attitude towards the social partners.

\section{Romania}

One of the first signs that the socialist regime of Romania had ended in December 1989 was the declaration that trade union membership was no longer compulsory. Together with other social organisations, for the first time in forty years, unions could imagine themselves free from state power. The new Constitution adopted in 1991 confirmed the right of individuals to form trade unions, as independent and non-political organisations; more specific laws on trade unions and industrial relations confirmed and detailed this status.

In short time, trade unions mushroomed at all levels and in all sectors. Currently, there are five representative trade union confederations at the national level. Once the primary issue of dividing the patrimony of the Communist trade union had been resolved, the rest of the first decade of transition was a period in which these unions searched for their identity. In this period, unions formed and maintained alliances with political parties towards which they felt ideologically close. Currently, Romanian trade unions are among the most politicised unions in eastern Europe, their party closeness ${ }^{17}$ being translated not only in terms of electoral support (at least in terms of

16 The Labour Code adopted in 2002 contains many features to increase labour market flexibility, which was a long-lasting demand of employer organisations. Both Solidarity and OPZZ planned protests and filed requests with the Constitutional Tribunal so as to verify the Code's constitutionality (Czarzasty, 2002). 
declarations of support), but also in terms of the participation of union leaders in government (Kideckel, 2001). ${ }^{18}$

Social dialogue in Romania was legislated for relatively late (1997), when several laws on industrial relations were passed and the main tripartite body, the Economic and Social Council (ESC), was created. ${ }^{19}$ Before 1997, social dialogue was regulated though the international conventions to which Romania adhered and managed through the Tripartite Secretariat for Social Dialogue, created at the initiative of the government in 1993. The Secretariat was an independent, non-governmental body which had the purpose of setting up the legislative and institutional framework required for social dialogue (Preda, 2006; Mihaes and Casale, 1999).

The ESC has an advisory role in devising social and economic strategies and policies, settling conflicts and opening, promoting and developing social dialogue and solidarity. The areas in which the ESC have to be consulted include restructuring and the development of the national economy, privatisation, labour-related issues, wages, social protection, education and research. Draft bills in these areas have to be submitted to the ESC and they carry its positive or negative opinion (in an advisory note) into parliament, for the length of the legislative process until they become laws. ${ }^{20}$ In 2003, the law on the ESC was amended. Currently, the ESC's opinion is required in matters which are not directly related to draft bills, such as strategies and planning (Law on ESC, www.ces.ro). ${ }^{21}$ Currently, the chair of the ESC is a representative of the government.

The Law does not specify any conditions related to the exchange of information inside the ESC. This offers the government quite a large amount of scope for (in)action. The ESC is not explicitly concerned with the state budget; therefore, the government is not obliged to discuss it with its social partners. Therefore, the latter have, more often than not, incomplete information regarding planned expenditure and revenues. It is not clear to what extent the representatives of the government present policy reports during ESC plenary sessions. It is reasonable to expect that they justify the government's position, but it is very unlikely that they do more than that.

17 The five representative union confederations have different political orientations: CNSLR-Frăția and BNS have a social democratic orientation; Cartel Alfa and CSDR present themselves as Christian democratic; while Meridian (the newest union to gain national representation) is independent.

18 Between 1996 and 1999, a former trade union leader (Victor Ciorbea) was Prime Minister in the first right-wing government of Romania. Miron Mitrea (another former trade union leader) was Minister of Public Work, Transport and Housing in the social democratic government (2000-2003); in 2003, he was appointed Minister of Tourism.

19 In addition to this national body, so-called social dialogue commissions were created at the level of ministries and prefectures.

20 If the ECS fails to deliver an opinion, the draft enters parliament with the note that the opinion of the ECS was requested.

21 The number of bills submitted to the ESC for approval has grown yearly since 1997, but the social partners complain that, in reality, the ESC approves increasingly fewer regulatory proposals than are published in the Official Monitor (earlier data is not available but, for 2003 and 2004, the rate of approval stood at $49.7 \%$ and $38 \%$ respectively) (Mihaes and Casale, 1999). 
Can trade unions punish any non-collaborative attitude of the government? Romanian unions do actively express their discontent. However, many strikes or demonstrations have been organised in response to enterprise-related problems. When collective agreement negotiations stalled, the unions threatened nationwide strikes, but they rarely implemented such threats. ${ }^{22}$ The miners' outbursts, which led to the fall of the government in 1990 and which produced considerable damage both in 1991 and 1999, were anything but union protests against government economic policies. Once the ESC started to function, the trade unions never boycotted it although they did threaten to do so, apparently preferring instead public declarations through the mass media. This strategy may be effective in keeping unions in the public eye, but it is less effective in forcing an actual change in government attitudes towards the social partners and in policy-making. ${ }^{23}$

It is unclear to what extent the politicisation of Romanian trade unions is a chance or a curse. It is a chance for those unions whose allies are in power. Some authors, however, argue that closeness to a political party encourages inter-union competition, adds ideological division and makes consensus more difficult to achieve. For the majority of the 1990s, governments had their allies and their opponents among the unions; a situation which was perpetuated inside the ESC. The union movement was fractured over the issue of the division of the assets of the former Communist union movement. Only recently (after 2003) have the main union confederations been able to overcome their ideological divisions and ambitions and stage common positions, thus enhancing their voice in social dialogue (Preda, 2003). For the period under analysis in this article, however, the unions were too disunited to counterbalance the government position.

\section{Slovakia}

Slovak trade unions benefit from strong legislation which encourages and protects their organisations. Items of legislation, such as acts on labour relations, acts on employment and acts on wages and social security, complement the basic constitutional rights and ensure that trade unions form and function as organisations independent of political bodies, focusing on the representation of labour interests.

The most important organisation of employees in Slovakia is the Confederation of Trade Unions of the Slovak Republic (KOZ SR). KOZ is the only representative organisation of labour at the level of the country's tripartite institution. Like its Czech

22 In 1999, the unions put forward a long list of demands and threatened a general strike if they were not met. The list of demands was extremely comprehensive - from bread-andbutter issues to political issues. The latter, which touched upon critical issues of economic and social policy-making, were formulated in extremely broad terms which, in fact, left a lot of space for dissension between the unions themselves. The general strike did not happen.

23 What they did achieve was more in terms of the extraction of certain benefits, like wage increases or the postponement of certain decisions. 'However, at the national level the labour confederations tried to impose political, social and economic modifications. Not one of these attempts succeeded. However, at the beginning at least, the pressure exercised by the working class through the mediation of the unions was sufficiently large to make those seeking power bow to them.' (Pasti, 1995). 
counterpart, KOZ was careful to maintain its independence. In 1998 it did campaign against Meciar's party (HZSD), but it did so in co-operation with a broad range of civil society organizations (Stein, 2001). After the electoral success of the opposition, $\mathrm{KOZ}$ returned to its non-aligned attitude and became active only in issues related to labour, mostly within CESA. If KOZ adopted non-political alignment as a:

Lasting principle of independence and legitimacy,' (Stein, 2001)

the same cannot be said, however, of some of the trade union leaders who gained parliamentary status by running on party lists; once in parliament, they became less trade unionists and more party members (Stein, 2001).

CESA, the tripartite body of the Slovak Republic, was created while the country was still part of Czechoslovakia and was maintained after the 1993 break-up. CESA resulted from a freely-entered agreement between unions, employers and the state to recognise and respect each other's individual and collective rights. CESA was based on the mutual recognition of the legitimacy of the other partners. According to the founding statute, CESA is an independent negotiating body which aims (through negotiation) to reach agreement and to make statements regarding basic economic, social, wage, labour law and employment issues (Machalikova, 1999). CESA's conclusions and statements take the form of recommendations to the government and parliament. When decisions are approved by all represented parties, they are binding on all members.

The union movement began under relatively favourable auspices - with a liberal legislation which ensured the independence of trade unions from political encroachment. After the Velvet Divorce, the Slovakian union movement maintained a roughly unitary structure. Theoretically therefore, there was a good basis for active union involvement in the public sphere and for the building of a constructive relationship with the government. However, the Meciar government adopted an attitude of:

Systematic disregard of the unions and the tripartite council. (Ost, 2000)

According to CESA's statute, the frequency of meetings between partners was intended to be relatively flexible, stating that meetings would be held as necessary. Under the Meciar government, 'as necessary' became increasingly rare as the government kept postponing meetings. The government was not required to submit any documents to the tripartite body. Therefore, when meetings did take place, given that the government would not provide relevant information (Ost, 2000), the social partners were thus stripped of the basic mechanisms with which to ask the government to justify or explain the rationale for its decisions. In 1997, KOZ withdrew from CESA.

The coming to power of the opposition did not bring significant changes, apart from the reinstatement of the tripartite body. The new 1999 law on economic and social partnership maintained the pattern of high recognition, but low effective power. It codified the reconstituted CESA's organisational setup and procedural rules, but it did not require the government to submit legislation to parliament in line with the outcome of negotiations - which left agreements reached through the 'social dialogue' subject to the will and ability of the government to implement them (Stein, 2001; 
Kohl and Platzer, 2004). That the Council's decisions remained non-binding prompted stark union criticism regarding the (potential) effectiveness of the Council.

From its inception, tripartism in the Slovak Republic was based on the principle of voluntary co-operation and the commitment of the parties to dialogue as a means of resolving conflicts or finding solutions. The main drawback is that the lack of a legal foundation which would codify rules of behaviour, rights and obligations, creates the opportunity for the government to shortcut dialogue and impose unilateral solutions. ${ }^{24}$

Did the unions have, or use, other means to make the government accountable? A strong legal basis for labour militancy did exist, but it was rarely used. 'Warning strikes' and strike threats have been frequent, but sustained mobilisation has been largely absent (Stein, 2001). ${ }^{25}$ The lack of effectiveness of these actions is evident in that the Meciar government continued repeatedly to ignore union requests and to break signed agreements. After the Meciar government was ousted from power, unions became even more quiescent and, until 2002, no strike was recorded (Eurofound 2004d). ${ }^{26}$

From 1990 on, KOZ remained committed to tripartism as the means to resolve conflicts and through which to press its demands, in spite of its relative ineffectiveness. However, in 1997 it withdrew from tripartite negotiations (returning only in 1999, when the new government re-created the tripartite body). It might be argued that the withdrawal was a reaction to the government's non-cooperative attitude. However, that the withdrawal did not come earlier suggests that the government's attitude was not a strong enough cause. An alternative explanation suggests that the $\mathrm{KOZ}$ withdrawal was determined by the government's attempts to encroach upon the tripartite body, which was perceived as a threat to unions' credibility as representatives of workers' interests (Stein, 2001: 72). The new government re-instated the tripartite body, both at KOZ's demand and under the pressure to ensure social cohesion and acceptance for the tough measures needed to pull the economy out of the fiscal and current account crisis in which the Meciar government had left it.

In spite of a visible weakening, the unity of Slovak labour contributed to the institutionalisation of tripartism and the creation of a legislative framework which ensures a relatively good protection for labour. However, labour strength should not be overestimated. This overview of union-government interactions suggests that its successes are largely the result of government goodwill and of a certain amount of international pressure while only to a lesser extent are they the result of union actions.

\section{Some concluding remarks}

Eastern European trade unions are weak. Their weakness comes in various forms: from a continuous loss of membership to toothless collective bargaining; and from low and ineffectual strike action to minimal influence over public policy. ${ }^{27}$ In spite of this weakness, it is considered by many that unions still have something to say. The

24 As of December 2004, the tripartite institution in Slovakia has a legal basis.

25 By the end of 1997, only 34 strikes had been recorded $(1991-21 ; 1992-5 ; 1993-1$; 1994 - 1; 1997-6). (Eurofound, 2004 SK).

26 In 2001, a two-hour strike was cancelled due to a lack of preparedness (Eurofound, 2004d). 
institutional and legal structures created around unions that are meant to empower them are modelled after neo-corporatist western institutions.

Two powerful contemporary discourses - the neo-corporatist and that of the role of civil society - attribute new roles to trade unions: they are expected not only to take care of the bread-and-butter issues of labour but also to become more involved in policy-making and decision-making, increasingly acting as a counterbalance to the government. They are being asked to be more active as actors involved in horizontal accountability. But can unions be the strong accounting actors they are expected to be? This is the central question explored by this article.

In order to answer it, on the basis of the literature on accountability, several conditions which enable a given institutional actor to be an effective accounting actor were identified. Briefly, if trade unions are to be effective accounting actors, they have:

- to be independent of the government

- to interact with the government in a formal setting which specifies the conditions of account giving

- to receive as complete a set of information as possible

- to be regarded as legitimate by, and be relatively equal to, the accountable actor

- to be able to inflict some sort of punishment if the account giving is not satisfactory.

This article examined trade unions in Bulgaria, Czech Republic, Hungary, Poland, Romania and Slovakia.

In each of these countries, the independence of trade unions is guaranteed and protected by the constitution. Often, unions have developed links with political parties in order to stay in the public eye, to have their demands fulfilled when their allies are in power and, last but not least, to secure the careers of union leaders. However, there are degrees of the political implication of unions: in the Czech Republic and Slovak Republic, unions maintained their independence; in Hungary and Bulgaria, they became highly politicised in the first years of transformation before subsequently softening their political character; and in Romania and Poland, unions are still highly divided on ideological grounds and, most importantly, have been part of government. In Poland, especially, it was difficult for many years to separate Solidarity-the union from Solidarity-the party. Heavy politicisation has a double negative impact on unions as accounting actors: on the one hand, they are too close to the political sphere to be impartial observers or analysts; on the other hand, politicisation means the division of unions along ideological lines, which weakens the union movement vis-à-vis the government.

The second condition referred to the formal framework within which the exchange between unions and the government takes place. Such institutions exist in all the countries analysed - the tripartite bodies - with these being created explicitly to put the social partners and the government face-to-face; they provide the space within which the government and the social partners deliberate, negotiate and make decisions regarding public policies and development strategies.

27 However, the inability of unions to ensure that their members do not lose their jobs or receive higher salaries should not be considered a clear sign of their weakness; rather, it is a sign of the strength of the crisis/recession and the constraints it puts on the government. 
This condition is only partly met in each of the countries examined in this article. The first problem is that the results of the discussions in the tripartite body are not binding on the government; the input of the social partners is only advisory and/or consultative. The second problem is that the tripartite bodies are not conceived as places in which the representatives of the government report regularly on policies and/or strategies. At best, they provide ex ante justifications for draft proposals or plans. The only place where the government can be asked to give account ex post and ex ante is parliament. In three cases (Czech Republic, Hungary and Slovakia), the tripartite institution is based on voluntary agreement between the parties involved and on their 'goodwill'. This reads well in statements of intent, but the absence of legal bindings allows the stronger actors (q.v. governments) to alter interactions at will. In cases where a law on the tripartite institutions does exist (Bulgaria, Poland and Romania), it does not regulate the parties' rights and obligations and does not stipulate 'punishment' for misbehaviour. Therefore, even in these cases, the quality of interaction depends on the 'goodwill' of the partners. In sum, the tripartite institutions do not provide a proper formal framework in which unions may behave as accounting actors.

The third condition referred to is the exchange of information between unions and government. The common denominator of all the six countries is the inadequate circulation of information. All the unions complain about the government not providing them with appropriate and complete information. Sometimes, governments have bypassed the tripartite body, cutting out even the ex ante justification of actions to the social partners. It is not possible to argue that governments have displayed a permanently non-cooperative attitude, but an incomplete and inconstant flow of information clearly does incapacitate unions in their role as accounting actors.

The balance of power is biased ab initio in favour of the government, on several accounts: unions are physically weak; the government has the advantage of being a state institution; and tripartism is, in most cases, government-initiated. However, unions can - at least theoretically - function as a counterbalance if they present a united front. Among the unions in the countries analysed here, only CMKOS (Czech Republic) and KOZ (Slovakia) have a unitary stance. In Poland and Bulgaria, the union scene is bipolar but, for most of the period, the two unions have adopted a confrontational attitude towards each other. The same was true of the pluralist structure of the union movements in Romania and Hungary. It is equally true that the unions in these last four cases have recently diminished their ideological or partisan positions in order to co-operate more and to speak with the same voice to the government. However, for the period under analysis, more confrontation and less co-operation was the attitude of the unions towards each other, which weakened their ability to focus on the government and its actions.

Last but not least, the paper looked at the ability of unions to punish any non-cooperative attitude on the part of the government. Unions have used their rights and abilities to organise and co-ordinate social protests but, as a rule, these have reflected the disunity of union movements: most of the protests were organised in response to local problems and only rarely unions have co-ordinated their efforts. Unions have also often used the mass media to attract attention to certain policies or decisions. One could generously equate such actions with ex post criticism of the direction of reforms, but it is clear that they scarcely convinced governments to fine tune their policies, as Stark and Bruszt expected them to do, or to change their attitude in interac- 
tions with the social partners. The most they were able to do was to postpone some policy steps, to extract additional resources, to increase unions' public visibility and to erode the public support of the governing parties. ${ }^{28}$ However, it is not clear (and with the data at hand it cannot be proved) whether unions' actions undermined governments' image to the point of determining electoral defeat. Nevertheless, the issue is not whether unions can resort to some 'punitive' measures; obviously they can. The problem is whether their actions have the expected effect on government or not. Does it make the government 'behave better' in the next round of decision-making, or not? The information available so far, at least for the period analysed by this article, suggests a negative answer: governments have continued their policies and maintained relatively non-cooperative attitudes.

To sum up, this article argued that eastern European trade unions are not effective accounting actors. Unions present themselves as willing to take on more active roles in policy-making, but they cannot do so largely as a result of the constraints of the institutional framework. The tripartite bodies established in this direction have created the space in which labour demands may be brought to the political level but, at the same time, they constrain the ways in which labour representatives are able to participate in policy-making. The tripartite bodies have not been established to enhance the accountability of governments; at best, one can see them as fora in which governments have the opportunity to justify certain decisions, thereby ensuring a 'soft accountability'. These findings confirm Offe's assertion that neo-corporatism imposes a political trade-off on social actors: in exchange for official recognition and privileged access to the centres of the state's decision-making powers, an organised interest group accepts limitations on the scope and content of its demands and on its tactics $(1981) .{ }^{29}$

However, the present analysis suggests a reason for the lack of effectiveness of the accountability relationship: the very limitations of the institutional framework itself. An analysis of the functioning of these institutions suggests that all they do is create the impression of a similarity to the prescribed solutions coming out of theories and from western practices. They seem to be a space in which government justifies its choices, a place in which negotiations take place and in which policies are created. However, these institutions have been created by eastern European governments to serve their own purposes: the need to obtain acquiescence for reforms and social peace from the social partners, and a recognition of the fulfilling of certain standards of the international organisations. Therefore, eastern European unions are able to hold governments accountable only as far as the governments themselves want to be so. And this is a far cry from the unions being accounting actors.

28 It is not seldom that governments who felt that they have lost public support have increased social expenditure in the year/months prior to elections (OECD, various years).

29 Offe labels this effect 'neo-corporatist depoliticisation' and observes that its effect is asymmetrical with respect to different types of organised interests: by determining that working class organisations moderate their demands and adopt a 'responsible' attitude, neo-corporatism restrains union power more than it does that of employer associations, whose power does not reside in organisation (Offe, 1981). 


\section{References}

Amsden, Alice, Jacek Kochanowicz and Lance Taylor (1994) The Market Meets its Match. Restructuring the Economies in Eastern Europe Cambridge, MA: Harvard University Press.

Avdagic, Sabina (2003) Accounting for Variations in Trade Union Effectiveness: State-Labor Relations in East Central Europe MPIfG Discussion Papers 06/03, Max Planck Institute for the Study of Societies: Cologne.

Casale, Giuseppe (Ed.) (1999) Social Dialogue in Central and Eastern Europe International Labour Office: Budapest.

Chabal, Patrick and Jean-Paul Daloz (2006) Culture Troubles: Politics and the Interpretation of Meaning London: Hurst \& Company.

Crowley, Stephen and David Ost (Eds.) (2001) Workers after Workers' States. Labor and Politics in Post-Communist Eastern Europe Lanham: Rowman \& Littlefield Publishers.

Czarzasty, Jan (2002) Amended Labour Code adopted available online at http:// www.eurofound.europa.eu/eiro/2002/09/feature/p10209107f.html [accessed on 21 August 2007).

Detchev, Teodor (2003) 'Evolution of the model of industrial relations in Bulgaria 1989-2002' South-East Europe Review 6(1-2): 45-58.

Diamond, Larry (1994) 'Rethinking civil society. Towards democratic consolidation' Journal of Democracy 5(3): 5-17.

Dimitrova, Dimitrina (1999) 'Tripartism and Industrial Relations in Bulgaria' in Giuseppe Casale (Ed.) Social Dialogue in Central and Eastern Europe International Labour Office: Budapest, pp. 63-91.

Dølvik, Jon Erik (2003) Who determines future working life policies in Norway? A researcher's view paper presented at NHO-Conference 'The EU and Norwegian working life: Who determines the development?' 31 January.

Dubrow, Geoffrey (2003) Strengthening Horizontal Accountability in the Balkans paper presented at the conference 'Southern Europe, Moving Forward' Ottawa, Canada, 23-24 January.

Eurofound (2004a) Social dialogue and conflict resolution in the Czech Republic European Foundation for the Improvement of Living and Working Conditions.

Eurofound (2004b) Social dialogue and conflict resolution in Hungary European Foundation for the Improvement of Living and Working Conditions.

Eurofound (2004c) Social dialogue and conflict resolution in Poland European Foundation for the Improvement of Living and Working Conditions.

Eurofound (2004d) Social dialogue and conflict resolution in Slovakia European Foundation for the Improvement of Living and Working Conditions.

Evans, Peter (1995) Embedded Autonomy. States and Industrial Transformation Princeton: Princeton University Press. 
Gardawski, Juliusz (2002) The Development of the National Tripartite Commission available at: http://www.eurofound.europa.eu/eiro/2002/10/feature/pl0210106f.html [accessed 21 August 2007.

Gerschenkron, Alexander (1962) Economic Backwardness in Historical Perspective: A Book of Essays Cambridge: The Belknap Press of Harvard University Press.

Gradev, Grigor (2001) 'Bulgarian Trade Unions in Transition: The Taming of the Hedgehog' in Stephen Crowley and David Ost (Eds.) Workers after Workers' States. Labor and Politics in Post-Communist Eastern Europe Lanham: Rowman \& Littlefield Publishers.

Héthy, Lajos (1999) 'Tripartism and industrial relations in Hungary' in Giuseppe Casale (Ed.) Social Dialogue in Central and Eastern Europe International Labour Office: Budapest, pp. 180-201.

Keohane, Robert O and Joseph S. Nye (2000) 'Introduction' in Joseph S. Nye, Jr. and John D. Donahue (Eds.) Governance in a Globalizing World Washington D.C: Brookings Institution Press, pp. 1-41.

Kideckel, David (2001) 'Winning the Battles, Losing the War: Contradictions of Romanian Labor in Postcommunist Transformation' in Stephen Crowley and David Ost (Eds.) Workers after Workers' States. Labor and Politics in Post-Communist Eastern Europe Lanham: Rowman \& Littlefield Publishers.

Kohl, Heribert and Hans-Wolfgang Platzer (2004) Industrial Relations in Central and Eastern Europe: Transformation and Integration. A comparison of the eight new EU member states ETUI: Brussels.

Kroupa, Aleš and Jaroslav Hála (2006) Capacity building for social dialogue in Czech Republic European Foundation for the Improvement of Living and Working Conditions.

Kubicek, Paul (2002) 'Civil Society, Trade Unions and Post-Soviet Democratisation: Evidence from Russia and Ukraine' Europe-Asia Studies 54(1): 603-624.

Kubicek, Paul (2000) Unbroken Ties. The State, Interest Associations and Corporatism in Post-Soviet Ukraine Ann Arbor: University of Michigan Press.

Kubínková, Marcela (1999) 'Tripartism and Industrial Relations in the Czech Republic' in Giuseppe Casale (Ed.) Social Dialogue in Central and Eastern Europe International Labour Office: Budapest, pp. 118-145.

Leiber, Simone (2005) Implementation of EU Social Policy in Poland: Is there a Different 'Eastern World of Compliance'? paper presented at the Ninth Biennial International Conference of the European Unions Studies Association (EUSA), Austin, Texas: 31 March-2 April.

Lehmbruch, Gerhard (1979) 'Liberal Corporatism and Party Government' in Gerhard Lehmbruch and Phillipe Schmitter (Eds.) Trends Towards Corporatist Intermediation Beverly Hills, CA: Sage.

Machalikova, Anna (1999) 'Tripartism in the Slovak Republic' in Giuseppe Casale (Ed.) Social Dialogue in Central and Eastern Europe International Labour Office: Budapest, pp. 288-305. 
Matthes, Claudia-Yvette and Peggy Thode (2001) Assessing the Impact of Veto Players and Political Skills on the Outcomes of Economic Reforms in Central European Countries paper presented at the $13^{\text {th }}$ Annual Meeting on Socio-Economics, University of Amsterdam, Amsterdam, The Netherlands: 28 June-1 July.

Mihaes, Cristina and Giuseppe Casale (1999) 'Industrial Relations in Romania' in Giuseppe Casale (Ed.) Social Dialogue in Central and Eastern Europe International Labour Office: Budapest, pp. 270-288.

Nikolov, Boyko et al. (2004) Country Report: Understanding Reform: A Country Study for Bulgaria Global Development Network Southeast Europe (GDN-SEE), research area: 'Understanding reform'.

O'Donnell, Guillermo (1998) 'Horizontal Democracy in New Democracies' Journal of Democracy 9(3): 112-126.

OECD Economic Surveys, various years and countries.

Offe, Claus (1981) 'The Attribution of Public Status to Interest Groups: Observations on the West German Case' in Susanne Berger (Ed.) Organising Interests in Western Europe: Pluralism, Corporatism and the Transformation of Politics Cambridge: Cambridge University Press.

Ost, David (2000) 'Illusory Corporatism in Eastern Europe: Neoliberal Tripartism and Postcommunist Class Identities' Politics and Society 24(4): 503-530.

Ost, David (2001) 'The Weakness of Symbolic Strength: Labor and Union Identity in Poland, 1989-2000' in Stephen Crowley and David Ost (Eds.) Workers after Workers' States. Labor and Politics in Post-Communist Eastern Europe Lanham: Rowman \& Littlefield Publishers.

Ost, David (2002) 'The Weakness of Strong Social Movements: Models of Unionism in the East European Context' European Journal of Industrial Relations 8: 33-51.

Pasti, Vladimir (1995) România în Tranziție: Cãderea în Viitor Bucharest: Editura Nemira.

Pollert, Anna (2001) 'Labor and trade unions in the Czech Republic, 1989-2000' in Stephen Crowley and David Ost (Eds.) Workers after Workers' States. Labor and Politics in Post-Communist Eastern Europe Lanham: Rowman \& Littlefield Publishers.

Preda, Diana (2006) Capacity building for social dialogue in Romania European Foundation for the Improvement of Living and Working Conditions.

Preda, Diana (2003) The development and current situation of trade unions available at: http://www.eurofound.europa.eu/eiro/2003/07/feature/ro0307101f.html [accessed 20 August 2007].

Schedler, Andreas (1999) 'Conceptualizing Accountability' in Andreas Schedler, Larry Diamond and Marc F. Plattner (Eds.) The Self-Restraining State. Power and Accountability in New Democracies Boulder, CO and London, UK: Lynne Rienner Publishers, pp. 13-28.

Schedler, Andreas, Larry Diamond and Marc F. Plattner (Eds.) The Self-Restraining State. Power and Accountability in New Democracies Boulder, CO and London, UK: Lynne Rienner Publishers, pp. 13-28. 
Schmitter, Philippe C (1974) 'Still the century of corporatism?' Review of Politics 36(1): 85-131.

Schmitter, Philippe C (1982) 'Reflections on Where the Theory of Neo-Corporatism Has Gone and Where the Praxis of Neo-Corporatism May Be Going' in Gerhard Lehmbruch and Philippe C. Schmitter (Eds.) Patterns of Corporatist Policy-Making London: Sage Ltd. p. $263 \mathrm{ff}$.

Schmitter, Philippe C (1983) 'Democratic Theory and Neocorporatist Practice' Social Research 50(4), Winter.

Schmitter, Philippe C (1997) 'Civil society east and west' in Larry Diamond and Marc F. Plattner (Eds.) Consolidating the Third Wave Democracies: Themes and Perspectives London: Johns Hopkins University Press.

Schmitter, Philippe C (2004' 'The Ambiguous Virtues of Accountability' Journal of Democracy 15(4).

Scholte, Jan Aart (2002) 'Civil Society and Democracy in Global Governance' Global Governance 8(3): 281-304.

Skarby, Elina (2006) Capacity building for social dialogue in Bulgaria European Foundation for the Improvement of Living and Working Conditions.

Sobótka, Elzbieta (1999) 'The Role and Functioning of Tripartite Institutions in Social Dialogue at the National Level in Poland' in Giuseppe Casale (Ed.) Social Dialogue in Central and Eastern Europe International Labour Office: Budapest, pp. 63-91.

Stark, David and Laszlo Bruszt (1998) Postsocialist Pathways. Transformation of Politics and Property in Central and Eastern Europe Cambridge: Cambridge University Press.

Stein, Jonathan (2001) 'Neocorporatism in Slovakia: Formalizing Labor Weakness in a (Re)democratizing State' in Stephen Crowley and David Ost (Eds.) Workers after Workers' States. Labor and Politics in Post-Communist Eastern Europe Lanham: Rowman \& Littlefield Publishers.

Toth, Andras (2001) 'Failure of Social-Democratic Unionism in Hungary' in Stephen Crowley and David Ost (Eds.) Workers after Workers' States. Labor and Politics in Post-Communist Eastern Europe Lanham: Rowman \& Littlefield Publishers.

Väyrynen, Raimo (2004) Political Power, Accountability and Global Governance http://www.helsinki.fi/collegium/eng/Vayrynen/TampereClub.Governance.pdf. 